\title{
Turtle ectoparasites from the Pacific coastal region of Colombia
}

\author{
Mario Fernando Garcés-Restrepo ${ }^{1,4}$, Alan Giraldo ${ }^{I}$, John L. Carr ${ }^{1,2}$ \& Lisa D. Brown ${ }^{2,3}$ \\ ${ }^{1}$ Grupo de Investigación en Ecología Animal, Sección de Zoología, Departamento de Biología, \\ Facultad de Ciencias, Universidad del Valle-UNIVALLE, A.A. 25360, Cali, Colombia \\ ${ }^{2}$ Department of Biology and Museum of Natural History, University of Louisiana at Monroe - ULM, LA \\ 71209-0520, Monroe, Louisiana, United States of America \\ ${ }^{3}$ Department of Pathobiological Sciences, School of Veterinary Medicine, Louisiana State \\ University - LSU, LA 70803, Baton Rouge, Louisiana, United States of America \\ ${ }^{4}$ Corresponding author: Mario Fernando Garcés-Restrepo,e-mail: mariofgarces@gmail.com
}

GARCÉS-RESTREPO, M.F., GIRALDO, A., CARR, J.L. \& BROWN, L.D. Turtle ectoparasites from the Pacific coastal region of Colombia. Biota Neotrop. 13(3): http://www.biotaneotropica.org.br/v13n3/en/ abstract?article+bn01313032013

\begin{abstract}
This study provides an update on the ectoparasites (ticks and leeches) associated with Rhinoclemmys annulata and provides new accounts on the ectoparasites associated with R. nasuta, R. melanosterna and Kinosternon leucostomum from the Pacific coast of Colombia. The presence of Amblyomma sabanerae on $R$. nasuta and $R$. melanosterna provided two new host records for the tick species. Also, the documentation of A. sabanerae from the Department of Valle del Cauca represents a new department record for the species in Colombia. Placobdella ringueleti was identified from $R$. nasuta and $K$. leucostomum, which represents a new host record for the leech species, as well as a significant extension of the known range.

Keywords: tick, leech, Testudines, Rhinoclemmys annulata, Rhinoclemmys melanosterna, Rhinoclemmys nasuta, Kinosternon leucostomum, Amblyomma sabanerae, Placobdella ringueleti.
\end{abstract}

GARCÉS-RESTREPO, M.F., GIRALDO, A., CARR, J.L. \& BROWN, L.D. Ectoparasitos asociados a tortugas en la costa pacífica de Colombia. Biota Neotrop. 13(3): http://www.biotaneotropica.org.br/v13n3/pt/ abstract?article+bn01313032013

Resumen: Este estudio proporciona nueva información sobre ectoparásitos (garrapatas y sanguijuelas) encontrados en Rhinoclemmys annulata, y aporta nuevos registros sobre ectoparásitos asociados a R. nasuta, R. melanosterna y Kinosternon leucostomum en la costa pacífica de Colombia. La presencia de Amblyomma sabanerae en $R$. nasuta y $R$. melanosterna provee dos nuevos hospederos para esta especie de garrapata. Igualmente el reporte de $A$. sabanerae amplía el registro de esta especie en Colombia, al departamento del Valle del Cauca. $R$. nasuta y $K$. leucostomum, se constituyen en nuevos registros de hospederos para Placobdella ringueleti, e incrementa de manera significativa el rango de distribución geográfico conocido para esta especie de sanguijuela.

Palabras claves: garrapata, sanguijuela, Testudines, Rhinoclemmys annulata, Rhinoclemmys melanosterna, Rhinoclemmys nasuta, Kinosternon leucostomum, Amblyomma sabanerae, Placobdella ringueleti. 


\section{Introduction}

Turtles serve as hosts to a variety of blood-feeding ectoparasites, of which the most commonly encountered are ticks (Acari) and leeches (Hirudinea). In addition, ticks and leeches can serve as vectors of hemogregarine infections in reptiles (Burridge \& Simmons 2003). Given that turtles have been deemed one of the most endangered groups of vertebrates (Rhodin et al. 2011) and parasitism has been suggested as one of the many possible causes for their decline (Gibbons et al. 2000), advancements have been made to identify ectoparasite species associated with turtles and document potential threats to the health of the animals. Numerous studies exist documenting ectoparasites associated with turtles in North America (e.g., Ernst 1971, Hulse \& Routman 1982, Dodd 1988, Brooks et al. 1990, Graham et al. 1997, Siddall \& Gaffney 2004, Ryan \& Lambert 2005, McCoy et al. 2007, Readel et al. 2008, Ennen \& Qualls 2011), but few such studies exist for tropical turtles in South America (Fairchild et al. 1966, Guerrero 1996, Labruna et al. 2002, Robbins et al. 2003, de Campos-Brites \& Rantin 2004, Voltzit 2007).

Specifically, even though the country has the second highest turtle species richness in South America, Colombia has few records of ectoparasites associated with its native turtle species. Of the 27 turtle species known to inhabit continental Colombia (Castaño-Mora 1997, Asociación... 2011), two species-rich genera that lack sufficient ectoparasite data are Rhinoclemmys Fitzinger 1835 (Geoemydidae Theobald 1868) and Kinosternon Spix 1824 (Kinosternidae Agassiz 1857). Medem (1956) first reported the tick species Amblyomma crassum (Robinson 1926) parasitizing a specimen of Rhinoclemmys annulata (Gray 1860) collected in the Department of the Chocó, Colombia, and published two more accounts of the observed parasitism between A. crassum and $R$. annulata (Medem 1962a, b). Ernst \& Ernst (1977) recorded four species of the genus Amblyomma [A. cajennense (Fabricius 1787); A. dissimile Koch, 1844; A. rotundatum Koch, 1844 and $A$. sabanerae Stoll, 1891] as ectoparasites associated with Rhinoclemmys species in the Neotropics. The most commonly identified tick species, A. sabanerae, was collected from five species of Rhinoclemmys, including two specimens of $R$. annulata from Colombia. Ernst \& Ernst (1977) also recovered one leech of the genus Placobdella from one specimen of $R$. annulata from Panama, and Oceguera-Figueroa $\&$ Pacheco-Chaves (2012) recently reported $P$. ringueleti parasitizing $R$. annulata in Costa Rica.

Schmidt (1947) made note that ticks were routinely discovered on the head and neck region of Kinosternon leucostomum (Duméril \& Bibron in Duméril \& Duméril 1851) specimens from Panama. Wharton (1938) reported $A$. dissimile from $K$. leucostomum in Mexico and Medem (1962a, b) recorded the tick species $A$. crassum from $K$. leucostomum in the Department of the Chocó, Colombia. Additional Neotropical reports of ectoparasites infecting Kinosternon include extensive parasitism by ticks on Kinosternon scorpioides (Linnaeus 1766) from Central and South America (Berry \& Iverson 2011), and a record of A. sabanerae from Panama (Kinosternon sp.; Fairchild et al. 1966). A new leech species, Placobdella ringueleti López-Jiménez \& Oceguera-Figueroa, 2009, was described based on specimens from Kinosternon leucostomum in southern Mexico (López-Jiménez \& Oceguera-Figueroa 2009), and the same species was recently reported infecting $K$. scorpioides in Costa Rica (Oceguera-Figueroa \& Pacheco-Chaves 2012).

Five continental turtle species are known from the Department of Valle del Cauca in the central region of the Pacific coastal plain of Colombia (Corredor-Londoño et al. 2007). We present basic information on host and localities for ectoparasites associated with four of the five species. This adds to previous ectoparasite information available for $R$. annulata and $K$. leucostomum, and contributes new host information for two other species of Rhinoclemmys.

\section{Material and Methods}

Three species of Rhinoclemmys, R. nasuta (Boulenger 1902), $R$. melanosterna (Gray 1861) and $R$. annulata, and Kinosternon leucostomum postinguinale (Cope 1887) were examined for ectoparasites from mainland and island localities in western Colombia between April 2005 and July 2011. We examined turtles from three mainland localities in the Department of Valle del Cauca, Colombia on the Pacific coastal plain: Playa Chucheros $\left(3.93228^{\circ} \mathrm{N}\right.$, $\left.77.30784^{\circ} \mathrm{W}\right)$, San Pedro (3.83337 $\left.{ }^{\circ} \mathrm{N}, 77.24925^{\circ} \mathrm{W}\right)$, and San Isidro $\left(3.44972^{\circ} \mathrm{N}, 77.16487^{\circ} \mathrm{W}\right)$. Populations of the four turtle species were also examined from the continental island known as Isla Palma $\left(3.90019^{\circ} \mathrm{N}, 77.35597^{\circ} \mathrm{W}\right)$, which is within a few kilometers of the mainland sites Playa Chucheros and San Pedro (Figure 1).

Turtles were collected by hand at night (2000 to $2400 \mathrm{~h}$ ) from six streams on the island and eight streams on the mainland (three streams each at Playa Chucheros and San Pedro, and two streams from San Isidro). Once the turtles were collected, standard measurements of length and weight were taken, each individual was marked (Cagle 1939), sexed, and the external body surface was examined thoroughly for the presence of ectoparasites. All ectoparasites found were removed and preserved for later examination. For the two most abundant turtle species, $R$. nasuta and $K$. leucostomum, the number of specimens examined includes both original captures and recaptures as separate events. Ticks and leeches were preserved and stored in $70 \%$ ethanol (Knudsen 1966). In the last year, leeches were flattened and fixed with $10 \%$ formalin for $24 \mathrm{hr}$, we rinsed them with water before placing them in $70 \%$ ethanol for storage (Thorp \& Covich 2010). Ectoparasite specimens were transported to the Animal Ecology Research Laboratory at the Universidad del Valle in Cali for sorting by life stage for ticks (i.e., nymph, larva, adult male, and adult female) and by species for the two groups. Both taxa were then identified to species using keys and primary species descriptions (Fairchild et al. 1966, Soos 1969, Jones et al. 1972, Ringuelet 1976, Oceguera-Figueroa \& Siddall 2008, López-Jiménez \& Oceguera-Figueroa 2009, Oceguera-Figueroa \& Pacheco-Chaves 2012). Parasite voucher specimens were deposited in the Teaching Collection (CD) of the Zoology Department of the Universidad del Valle (Cali) and the catalog access numbers are presented below.

\section{Results}

A total of 639 R. nasuta, eight $R$. melanosterna, four R. annulata, and $74 \mathrm{~K}$. leucostomum specimens were collected and subjected to thorough ectoparasite examinations from the four localities. Of the four turtle species encountered, $87 R$. nasuta, four $R$. melanosterna, and two $R$. annulata from the island and two mainland populations (Playa Chucheros and San Pedro) possessed ticks. Leeches were not recovered from any turtles from Isla Palma; however, 59 R. nasuta and three $K$. leucostomum from the three mainland populations harbored leech infestations.

\section{Ixodidae Murray, 1877; Amblyomma Koch, 1844; Amblyomma sabanerae Stoll, 1891}

A total of 509 tick specimens were collected from the three Rhinoclemmys species, but none were found on K. leucostomum. The only tick species recovered was $A$. sabanerae, consisting of 385 larvae, 65 nymphs, 44 adult males, and 15 adult females (Table 1). Voucher specimens of $A$. sabanerae from each turtle species are as follows: $R$. annulata, CD 2737-2741, CD 2770; R. melanosterna, CD 2767-2769; and R. nasuta, CD 2614, CD 2663-2727, CD 2742- 


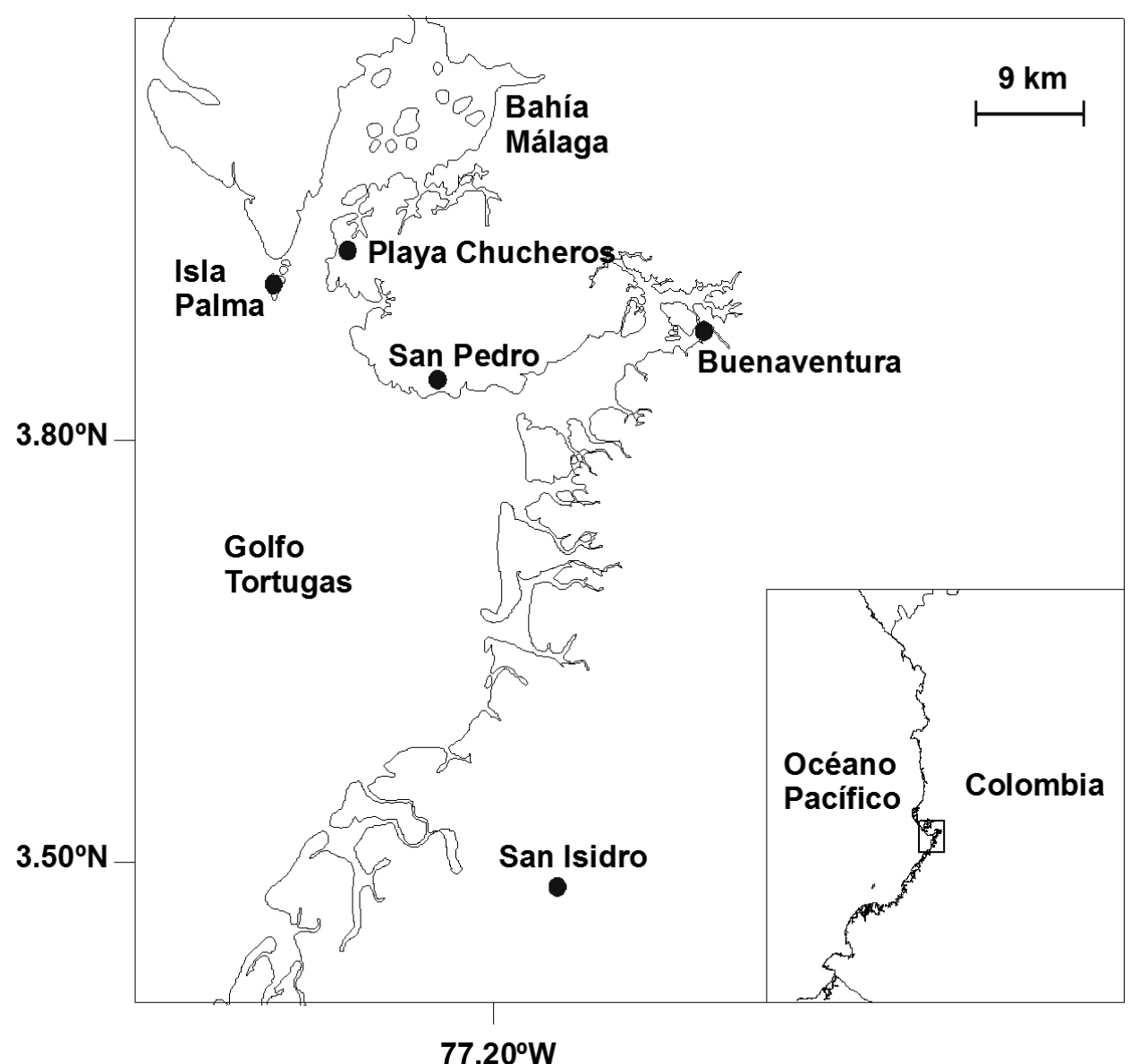

Figure 1. Map of the four collecting localities from coastal areas of the Department of Valle del Cauca, Colombia.

Table 1. Number of ectoparasite specimens for each turtle species.

\begin{tabular}{|c|c|c|c|c|c|}
\hline \multirow{2}{*}{ Species } & \multicolumn{4}{|c|}{ Amblyomma sabanerae } & \multirow{2}{*}{ Placobdella ringuelet } \\
\hline & Male & Female & Nymphs & Larvae & \\
\hline Rhinoclemmys nasuta & 34 & 11 & 61 & 175 & 463 \\
\hline Rhinoclemmys annulata & 8 & 3 & 3 & 210 & 0 \\
\hline Rhinoclemmys melanosterna & 2 & 1 & 1 & 0 & 0 \\
\hline Kinosternon leucostomum & 0 & 0 & 0 & 0 & 102 \\
\hline
\end{tabular}

2766. The immature stages (i.e., larvae and nymphs) have not been described for A. sabanerae (Guglielmone et al. 2003); therefore we followed the practice of "identifying" the preimaginal stages by their association with adult ticks present in the turtle population (Robbins et al. 2001). Robbins et al. (2001) described the hypostomal dentition of nymph specimens associated with adult $A$. sabanerae from $R$. areolata (Duméril \& Bibron in Duméril \& Duméril 1851) in Belize, and documented a $2 / 2$ hypostomal dentition for the nymphs, as opposed to the $3 / 3$ dental formula they attributed to $A$. dissimile, which is also known to parasitize Rhinoclemmys species (Ernst \& Ernst 1977). The nymphal dentition we observed varied between $2 / 2$ and $3 / 3$. The $2 / 2$ dental formula was observed in $65.5 \%$ of the nymphs recovered and the other $34.5 \%$ were $3 / 3$. The different dental formulae observed were not only among nymphs on different individual turtle hosts, but also between nymphs on the same turtle. The adult dental formula for $A$. sabanerae is $4 / 4$.

Rhinoclemmys nasuta and $R$. melanosterna represent new host records for $A$. sabanerae, adding another two species to the previously recorded five species of Rhinoclemmys [R. annulata, $R$. areolata, $R$. funerea (Cope 1876), R. pulcherrima (Gray 1856), $R$. punctularia (Daudin 1801)], parasitized by this tick (Ernst \& Ernst 1977, Burridge 2001, Robbins et al. 2001). Also, the presence of $A$. sabanerae in Valle del Cauca represents a new department record, south of the nearest reported locality where it was recovered from a R. annulata specimen in the Department of the Chocó (Ernst \& Ernst 1977). Osorno-Mesa (1940) previously reported A. sabanerae from Colombia based on Schulze (1937); however, there was no mention of the host or a specific locality. 


\section{Glossiphoniidae Vaillant, 1890; Placobdella Blanchard, 1893; Placobdella ringueleti López-Jiménez \& Oceguera-Figueroa, 2009}

A total of 565 leech specimens (including both adults and juveniles) were recovered over the course of this study, and Placobdella ringueleti was the only leech species identified from $R$. nasuta and K. leucostomum (Table 1). Voucher specimens of $P$. ringueleti from each turtle species are as follows: $R$. nasuta, CD 26062662, CD 2729-2736, and K. leucostomum, CD 2613, CD 2638-2639. This record of $R$. nasuta represents a new host for this leech, which is now recorded for two species of Rhinoclemmys. Oceguera-Figueroa $\&$ Pacheco-Chaves (2012) reported $P$. ringueleti from $R$. annulata in Costa Rica. This record of $P$. ringueleti in Colombia represents a new locality record and substantial range extension compared to the previously reported localities in Chiapas, Mexico (López-Jiménez \& Oceguera-Figueroa 2009), and Costa Rica (Oceguera-Figueroa \& Pacheco-Chaves, 2012). Kinosternon leucostomum is the host species from which the type material of $P$. ringueleti was obtained, and it has also been recorded from three other turtle species, Staurotypus triporcatus (Wiegmann 1828), Dermatemys mawii (Gray 1847) (López-Jiménez \& Oceguera-Figueroa 2009), and K. scorpioides (Oceguera-Figueroa \& Pacheco-Chaves 2012). The turtle taxon in southern Mexico corresponds with the nominal subspecies, $K . l$. leucostomum, and our specimens from western Colombia correspond with the subspecies $K$. l. postinguinale.

Although the taxonomic description of $P$. ringueleti was relatively recent (López-Jiménez \& Oceguera-Figueroa 2009), the key of Oceguera-Figueroa \& Pacheco-Chaves (2012) and several morphological characteristics helped us to identify the specimens. Externally, the leech specimens exhibit an ovate-lanceolate body shape, are brownish in color, and possess a single confluent dorsal stripe. The external feature that was diagnostic for this species identification was the presence of papillae on the dorsal surface of the posterior sucker (López-Jiménez \& Oceguera-Figueroa 2009). Internally, the leech specimens have two pairs of compact salivary glands and a pair of mycetomes (López-Jiménez \& OcegueraFigueroa 2009).

\section{Discussion}

The biogeographic affinities of the two ectoparasite species identified here coincide with those of the turtles. Turtles of the Chocoan biogeographic region have a strong relationship with the fauna of lower Central America, a relationship between the transAndean forest herpetofauna of Colombia and Ecuador and the Central American herpetofauna that has long been recognized (Savage 1966, Duellman 1979). The difference in distribution among sites for the two ectoparasite species is also of biogeographic interest in that the leech is absent from the island locality. Although it might be thought the intolerance of Placobdella for seawater could account for this distributional difference, there is no evidence that the turtles colonized the island from the mainland across the seawater barrier - more than likely given that the maximum depths of the area around the island at the entrance to Bahía Málaga are <50 m (Cantera et al. 1998, Guevara-Fletcher et al. 2011), the island would have been connected to the mainland within the last 18,000 years during the last glacial period (Martinez 1993).

The geographic range and host distribution of both ectoparasite species have been expanded with our observations. The tick Amblyomma sabanerae is now reported from seven of nine Rhinoclemmys species (Ernst \& Ernst 1977), with a distribution extending from western (Fairchild et al. 1966) and southern Mexico
(Paredes-León et al. 2008) at least as far south as Valle del Cauca in trans-Andean Colombia along the Pacific coast. The only record of the species from east of the Andes in South America is that of Ernst \& Ernst (1977) based on a nymph found on a specimen of $R$. punctularia in Suriname. Our new record of the leech Placobdella ringueleti extends the known range from Costa Rica to western Colombia (approximately $1000 \mathrm{~km}$ ), again a distributional pattern coinciding with the distribution of the host species, K. leucostomum, distributed from Mexico to South America. The species is now also recorded from two species of Rhinoclemmys, $R$. annulata in Costa Rica (Oceguera-Figueroa \& Pacheco-Chaves 2012) and R. nasuta in Colombia. Although there has been some question about whether or not there were species of Placobdella distributed in South America (Siddall et al. 2005, López-Jiménez \& Oceguera-Figueroa 2009), there are four species of Placobdella listed from cis-Andean South America (Christoffersen 2007, 2009), but this appears to be the first reported from the trans-Andean region. Both ectoparasite species recorded here have an apparently broad host tolerance among turtle species in lowland Neotropical localities.

The observed decline of turtles throughout the world has amplified the need for research that stands to clarify all possible reasons for their demise. The presence of ectoparasites on turtles is not novel; however, studies have shown that heavy sanguivore infestations could produce anemia and significantly limit the aerobic capacity and behavior of the host (Ernst \& Ernst 1977, Burridge 2005), thus reducing its viability in a population (Jacobson 1994). In addition, ticks and leeches are known vectors of hemogregarine infections in different kinds of reptiles, which could reduce hemoglobin concentrations (Burridge \& Simmons 2003, Ryan \& Lambert 2005, McCoy et al. 2007, Readel et al. 2008), and the lesions they create may serve as sites of pathogen entry and infection (Ernst \& Ernst 1977). The first step in monitoring the potential threats of ectoparasite associations with a host species is to identify the ectoparasite species involved.

\section{Acknowledgments}

We thank R. Fiorillo for comments and suggestions on the project. We thank R.G. Robbins, Walter Reed Army Medical Hospital, Washington, DC, for literature and assistance with tick identification, and A. Oceguera-Figueroa for advice and assistance with leech identification. We thank people who helped collect turtles and their ectoparasites during the course of this study: M. Merchán, J. Loaiza, J.V. Pérez, A. Quintero, and B. Valencia. This work was partially financed by the Grupo de Investigación en Ecología Animal and the Vicerrectoría de Investigaciones of the Universidad del Valle (CI:7707), the Herpetology Laboratory of the University of Louisiana at Monroe, the Turtle Research Fund of the ULM Foundation, and the Linnaeus Fund.

\section{References}

AGASSIZ, L. 1857. Contributions to the natural history of the United States of America. First Monograph. v.I. Part I. Essay on classification. Part II. North American Testudinata. Little, Brown and Co, Boston.

ASOCIACIÓN COLOMBIANA DE HERPETOLOGÍA - ACH. 2011. Plan Estratégico de Conservación para las Tortugas Continentales Colombianas. Asociación Colombiana de Herpetología, Medellín.

BERRY, J.F. \& IVERSON, J.B. 2011. Kinosternon scorpioides (Linnaeus 1766) - scorpion mud turtle. In Conservation biology of freshwater turtles and tortoises: A compilation project of the IUCN/SSC Tortoise and Freshwater Turtle Specialist Group (A.G.J. Rhodin, P.C.H. Pritchard, P.P. Van Dyke, R.A. Saumure, K.A. Buhlmann, J.B. Iverson \& R.A. Mittermeier, eds.) Chelon. Res. Monogr. 5, p.063.1-063.15.

BLANCHARD, R. 1893. Courtes notices sur les Hirudinées. X. Hirudinées de l'Europe boréale. Bull. Soc. zool. France 18:92-98. 
BOULENGER, G.A. 1902. Descriptions of new batrachians and reptiles from north-western Ecuador. Ann. Mag. Nat. Hist. 79:51-57. http://dx.doi. org $/ 10.1080 / 00222930208678538$

BROOKS, R.J., GALBRAITH, D.A. \& LAYFIELD, J.A. 1990. Occurrence of Placobdella parasitica (Hirudinea) on snapping turtles, Chelydra serpentina, in southeastern Ontario. J. Parasitol. 76(2):190-195. http:// dx.doi.org/10.2307/3283014

BURRIDGE, M.J. 2001. Ticks (Acari: Ixodidae) spread by the international trade in reptiles and their potential roles in dissemination of diseases. Bol. Entomol. Res. 91:3-23.

BURRIDGE, M.J. 2005. Controlling and eradicating tick infestations on reptiles. Comp. Cont. Educ. Pract. 27(5):371-376.

BURRIDGE, M.J. \& SIMMONS, L.A. 2003. Exotic ticks introduced into the United States on imported reptiles from 1962 to 2001 and their potential roles in international dissemination of diseases. Vet. Parasitol. 113:289320. http://dx.doi.org/10.1016/S0304-4017(03)00060-8

CAGLE, F.R. 1939. A system for marking turtles for future identification. Copeia 1939:170-173. http://dx.doi.org/10.2307/1436818

CANTERA, J.R., NEIRA, R. \& RICAURTE, C. 1998. Bioerosión en acantilados del Pacífico colombiano. Fondo FEN-Proyecto Biopacífico, Santa Fé de Bogotá.

CASTAÑO-MORA, O.V. 1997. Status of the tortoises and freshwater turtles of Colombia. In Proceedings: Conservation, Restoration and Management of Tortoises and Turtles - An International Conference (J. Van Abbema, ed.). New York Turtle and Tortoise Society, New York, p.302-306.

CHRISTOFFERSEN, M.L. 2007. Clitellate evolution and leech diversity: Glossiphoniidae excl. Helobdella (Annelida, Hirudinea, Rhynchobdellida) from South America. Gaia Scientia 1(2):131-140.

CHRISTOFFERSEN, M.L. 2009. A catalogue of Helobdella (Annelida, Clitellata, Hirudinea, Glossiphoniidae), with a summary of leech diversity, from South America. Neotrop. Biol. Conserv. 4(2):89-98. http://dx.doi. org/10.4013/nbc.2009.42.04

COPE, E.D. 1876. On the Batrachia and Reptilia of Costa Rica. In On the Batrachia and Reptilia of Costa Rica with notes on the herpetology and ichthyology of Nicaragua and Peru (E.D. Cope, ed.). J. Acad. Nat. Sci. Philadelphia (2)8(4)1875[1876]:93-154.

COPE, E.D. 1887. Catalogue of Batrachia and Reptilia of Central America and Mexico. Bull. U.S. Natl. Mus. 32:1-98. http://dx.doi.org/10.5479/ si.03629236.32

CORREDOR-LONDOÑO, G., KATTAN, G., GALVIS-RIZO, C.A. \& AMOROCHO, D. 2007. Tortugas del Valle del Cauca. Corporación Autónoma Regional del Valle del Cauca (CVC), Santiago de Cali.

DAUDIN, F.M. 1801. Histoire Naturelle, Générale et Particulière des Reptiles. Tome Second. Dufart, Paris.

DE CAMPOS-BRITES, V.L. \& RANTIN, F.T. 2004. The influence of agricultural and urban contamination on leech infestation of freshwater turtles, Phrynops geoffroanus, taken from two areas of the Uberabinha River. Environ. Monit. Assess. 96:273-281. http://dx.doi.org/10.1023/ B:EMAS.0000031733.98410.3c

DODD, C.K. 1988. Patterns of distribution and seasonal use of the turtle Sternotherus depressus by the leech Placobdella parasitica. J. Herpetol. 22:74-81. http://dx.doi.org/10.2307/1564358

DUELLMAN, W.E. 1979. The South American herpetofauna: a panoramic view. In The South American Herpetofauna: Its Origin, Evolution, and Dispersal (W.E. Duellman, ed.). Monograph of the Museum of Natural History, University of Kansas, Lawrence, p.1-28.

DUMÉRIL, A.M.C. \& DUMÉRIL, A.H.A. 1851. Catalogue methodique de la collection des reptiles du Museum d' Histoire Naturelle. Gide and Boudry, Paris.

ENNEN, J.R. \& QUALLS, C.P. 2011. Distribution and habitat utilization of the gopher tortoise tick (Amblyomma tuberculatum) in southern Mississippi. J. Parasitol. 97:202-206. http://dx.doi.org/10.1645/GE-2599.1

ERNST, C.H. 1971. Seasonal incidence of leech infestation on the painted turtle, Chrysemys picta. J. Parasitol. 57:32. http://dx.doi. org $/ 10.2307 / 3277749$
ERNST, C.H. \& ERNST, E.M. 1977. Ectoparasites associated with Neotropical turtles of the genus Callopsis (Testudines, Emydidae, Batagurinae). Biotropica 9:139-142. http://dx.doi.org/10.2307/2387671

FABRICIUS, J.C. 1787. Mantissa insectorum sistens species nuper detectas adiectis synonymis, observationibus, descriptionibus, emendationibus. Hafniae.

FAIRCHILD, G.B., KOHLS, G.M. \& TIPTON, V.J. 1966. The ticks of Panama (Acarina: Ixodoidea). In Ectoparasites of Panama (R.L. Wenzel $\&$ V.J. Tipton, eds.). Field Museum of Natural History, Chicago, Illinois.

FITZINGER, L.J. 1835. Entwurf einer systematischen Anordnung der Schildkröten nach den Grundsätzen der natürlichen Methode. Ann. Wiener Mus. Naturgeschichte 1:105-128.

GIBBONS, J.W., SCOTT, D.E. RYAN, T.J., BUHLMANN, K.A., TUBERVILLE, T.D., METTS, B.S., GREENE, J.L., MILLS, T., LEIDEN, Y., POPPY, S. \& WINNE, C. T. 2000. The global decline of reptiles, déjà vu amphibians. BioScience 50:653-666. http://dx.doi. org/10.1641/0006-3568(2000)050[0653:TGDORD]2.0.CO;2

GRAHAM, T.E., SAUMURE, R.A. \& ERICSON, B. 1997. Map turtle winter leech loads. J. Parasitol. 83:1185-1186. http://dx.doi.org/10.2307/3284384

GRAY, J.E. 1847. Description of a new genus of Emydidae. Proc. Zool. Soc. London 1847:55-56.

GRAY, J.E. 1856. Catalogue of shield reptiles in the collection of the British Museum. Part I. Testudinata (tortoises). British Museum, London.

GRAY, J.E. 1860. Description of a new species of Geoclemmys from Ecuador. Proc. Zool. Soc. Proc. Zool. Soc. London 1860:231-232.

GRAY, J.E. 1861. On a new species of water-tortoise (Geoclemmys melanosterna) from Darien. Proc. Zool. Soc. London 1861:204-205.

GUERRERO, R. 1996. Las garrapatas de Venezuela (Acarina: Ixodidae). Listado de especies y claves para su identificación. Bol. Mal. Salud Amb. 36:1-24.

GUEVARA-FLETCHER, C.E., CANTERA KINTZ, J.R., MEJÍALADINO, L.M \& CORTÉS, F.A. 2011. Benthic macrofauna associated with submerged bottoms of a tectonic estuary in tropical Eastern Pacific. J. Mar. Biol. 2011: Article ID 193759, 13p. http://dx.doi. org/10.1155/2011/193759

GUGliELmONE, A.A., ESTRADA-PEÑA, A., KEIRANS, J.E. \& ROBBINS, R.G. 2003. Ticks (Acari: Ixodida) of the Neotropical Zoogeographic Region. International Consortium on Ticks and Tickborne Diseases, Utrecht.

HULSE, A.C. \& ROUTMAN, E.J. 1982. Leech (Placobdella parasitica) infestations on the wood turtle, Clemmys insculpta. Herpetological Review 13:6

JACOBSON, E.R. 1994. Causes of mortality and diseases in tortoises: a review. J. Zoo. Wildlife. Med. 25:2-17.

JONES, E.K., CLIFFORD, C.M., KEIRANS, J.E. \& KOHLS, G. M. 1972. The ticks of Venezuela (Acarina: Ixodoidea) with a key to the species of Amblyomma in the Western Hemisphere. Brigham Young Univ. Sci., Biol. Ser. 17:1-40.

KNUDSEN, J.W. 1966. Biological Techniques. Harper \& Row, Publishers, New York.

KOCH, C.L. 1844. Systematische Uebersicht über die Ordnung der Zecken. Arc. Naturgeschichte 10(1):217-239.

LABRUNA, M.B., CAMARGO, L.M.A., TERRASSINI, F.A., SCHUMAKER, T.T.S. \& CAMARGO, E.P. 2002. Notes on parasitism by Amblyomma humerale (Acari: Ixodidae) in the State of Rondônia, Western Amazon, Brazil. J. Med. Entomol. 39:814-817. http://dx.doi.org/10.1603/00222585-39.6.814

LINNAEUS. C. 1766. Systema naturae per regna tria naturae, secundum classes, ordines, genera, species cum characteribus, differentiis. Synonymis, locis. 12th ed. Salvius, Stockholm, v.1.1..

LÓPEZ-JIMÉNEZ, S. \& OCEGUERA-FIGUEROA, A. 2009. New species of rhychobdellid leech (Hirudinea: Glossiphoniidae): a parasite of turtles from Chiapas, Mexico. J. Parasitol. 95:1356-1359. http://dx.doi. org/10.1645/GE-2128.1 
MARTINEZ, J.O. 1993.Geomorfologia. In Colombia Pacifico (P. Leyva, ed.) Santafé de Bogota, Fondo FEN-Proyecto Biopacifico, Tomo I, p.111-119.

McCOY, J.C., FAILEY, E.L., PRICE, S.J. \& DORCAS, M.E. 2007. An assessment of leech parasitism on semi-aquatic turtles in the western piedmont of North Carolina. Southeast. Nat. 6:191-202. http://dx.doi. org/10.1656/1528-7092(2007)6[191:AAOLPO]2.0.CO;2

MEDEM, F. 1956. Informe sobre reptiles colombianos (I). Noticia sobre el primer hallazgo de la tortuga Geoemyda annulata (Gray) en Colombia. Caldasia 7(34):317-325

MEDEM, F. 1962a. La distribución geográfica y ecología de los Crocodylia y Testudinata en el Departamento del Chocó. Rev. Acad. Colomb. Cienc. $11: 279-303$

MEDEM, F. 1962b. Informe final sobre la comisión a los ríos Atrato, San Juan y Baudó. Consejo Nal. Pol. Econ. Planeación; Documentos Desarrollo Chocó, Plan Fomento Regional Edit. Norma, Cali, Colombia.

MURRAY, A. 1877. Economic Entomology. Chapman and Hall, London, England.

OCEGUERA-FIGUEROA, A. \& PACHECO-CHAVES, B. 2012. Registros de sanguijuelas de Costa Rica y clave para la identificación de las especies con redescripción de Cylicobdella costaricae. Rev. Mex. Biodivers. 83:946-957.

OCEGUERA-FIGUEROA, A. \& SIDDALL, M.E. 2008. Placobdella lamothei $n$. sp. (Hirudinea: Glossiphoniidae), a new leech parasite of freshwater turtles from Estado de México, Mexico. Rev. Mex. Biodivers. 79:135-139.

OSORNO-MESA, E. 1940. Las garrapatas de la Republica de Colombia. Rev. Acad. Colomb. Cienc. 4(13):6-24.

PAREDES-LEÓN, R., GARCÍA-PRIETO, L., GUZMÁN-CORNEJO, C., LEÓN RÈGAGNON, V. \& PÉREZ, T.M. 2008. Metazoan parasites of Mexican amphibians and reptiles. Zootaxa (1904):1-166.

READEL, A.M., PHILLIPS, C.A. \& WETZEL, M.J. 2008. Leech parasitism in a turtle assemblage: effects of host and environmental characteristics. Copeia 2008:227-233.

RHODIN, A.G.J., WALDE, A.D., HORNE, B.D., VAN DIJK, P.P., BLANCK, T. \& HUDSON, R. 2011. Turtles in Trouble: The World's 25+ Most Endangered Tortoises and Freshwater Turtles-2011. Turtle Conservation Coalition [IUCN/SSC Tortoise and Freshwater Turtle Specialist Group, Turtle Conservation Fund, Turtle Survival Alliance, Turtle Conservancy, Chelonian Research Foundation, Conservation International, Wildlife Conservation Society, and San Diego Zoo Global], Lunenburg.

RINGUELET, R.A. 1976. Clave para las familias y generos de sanguijuelas (Hirudinea) de aguas dulces y terrestres de Mesoamérica y Sudamérica. Limnobios 1:9-19.

ROBBINS, R.G., PLATT, S.G., RAINWATER, T.R. \& WEISMAN, W. 2001. Statistical measures of association between Amblyomma sabanerae Stoll (Acari: Ixodida: Ixodidae) and the furrowed wood turtle, Rhinoclemmys areolata (Duméril \& Bibron) (Testudines: Emydidae), in northern Belize. P. Entomol. Soc. Wash. 103:54-59.
ROBBINS, R.G., DEEM S.L. \& OCCI, J.L. 2003. First report of Amblyomma humerale Koch (Acari: Ixodida: Ixodidae) from Bolivia, with a synopsis of collections of this tick from the South American Yellowfooted Tortoise, Geochelone denticulata (L.) (Reptilia: Testudines: Testudinidae). P. Entomol. Soc. Was. 105:502-505.

ROBINSON, L. E. 1926. Ticks. A Monograph of the Ixodoidea. Part IV. The Genus Amblyomma. Cambridge University Press, Cambridge.

RYAN, TJ. \& LAMBERT, A. 2005. Prevalence and colonization of Placobdella on two species of freshwater turtles (Graptemys geographica and Sternotherus odoratus). J. Herpetol. 39:284-287. http://dx.doi. org/10.1670/180-04N

SAVAGE, J.M. 1966. The enigma of the Central American herpetofauna: dispersals or vicariance? Ann. Mo. Bot. Gard. 69(3):464-547. http:// dx.doi.org/10.2307/2399082

SCHMIDT, K.P. 1947. A new kinosternid turtle from Colombia. Fieldiana (Zool.) 31(13):109-112.

SCHULZE, P. 1937. Beiträge zur Kenntnis der Zeckengattung Amblyomma. Z. Parasit. 9:690-694. http://dx.doi.org/10.1007/BF02122157

SIDDALL, M.E., BUDINOFF, R.B. \& BORDA, E. 2005. Phylogenetic evaluation of systematics and biogeography of the leech family Glossiphoniidae. Invertebr. Syst. 19:105-112. http://dx.doi.org/10.1071/ IS04034

SIDDALL M.E \& GAFFNEY, E.S. 2004. Observations on the leech Placobdella ornata feeding from bony tissues of turtles. J. Parasitol. 90:1186-1188. http://dx.doi.org/10.1645/GE-277R

SOOS, A. 1969. Identification key to the leech (Hirudinaidea) genera of the world, with a catalogue of the species VI. Family; Glossiphoniidae. Acta zool. Acad Sci. H. 15:397-454.

SPIX, J.B. 1824. Animalia Nova sive Species Novae Testudinum et Ranarum. Monachii, 53p.

STOLL, O. 1891. Amblyomma sabanerae. In Biologia Centrali-Americana, Arachnida, Acaridea 1886-1893 (O. Stoll, ed.). London, p v-xxi, 1-55.

THEOBALD, W. 1868. Catalogue of Reptiles in the Museum of the Asiatic Society of Bengal. J. Asiatic Soc., extra number, 88p.

THORP, J.H. \& COVICH, A.P. 2010. Ecology and Classification of North American Freshwater Invertebrates. 3rd ed. Academic Press, Boston.

VAILLANT, L.L. 1890. Histoire naturelle des annelés marins et d'eau douce. In Lombriciniens, Hirudiniens, Bdellomorphes, Térétulariesn et Planariens, v.3(2) (A. De Quatrefages \& L. Vaillant, eds.). Paris.

VOLTZIT, O.V. 2007. A review of Neotropical Amblyomma species (Acari: Ixodidae). Acarina 15:3-134.

WHARTON, G.W. 1938. Acarina of Yucatan caves. Carnegie I. Wash. 491:137-152

WIEGMANN, A.F.A. 1828. Beyträge zur Amphibienkunde. Isis von Oken $21(4): 364-383$. 